\title{
Targeting vasoactive peptides for managing calcific aortic valve disease
}

\section{Peltonen, Tuomas}

2017-02

Peltonen , T , Ohukainen , P , Ruskoaho , H J \& Rysä , J 2017 , ' Targeting vasoactive peptides for managing calcific aortic valve disease ' , Annals of Medicine , vol. 49 , no. 1 , pp. 63-74 . https://doi.org/10.1080/07853890.2016.1231933

http://hdl.handle.net/10138/309277

https://doi.org/10.1080/07853890.2016.1231933

unspecified

acceptedVersion

Downloaded from Helda, University of Helsinki institutional repository.

This is an electronic reprint of the original article.

This reprint may differ from the original in pagination and typographic detail.

Please cite the original version. 


\title{
Targeting vasoactive peptides for managing calcific aortic valve disease
}

\author{
Tuomas Peltonen, Pauli Ohukainen, Heikki Ruskoaho \& Jaana Rysä
}

Annals of Medicine, 49:1, 63-74, DOI: 10.1080/07853890.2016.1231933

Introduction

Calcific aortic valve disease (CAVD) represents a spec-trum of disease spanning from mild aortic valve scler-osis to severe aortic stenosis (AS) with hemodynamic instability (1). CAVD is the most common valvular heart disease in Europe and North America and its prevalence is increasing rapidly due to the aging of the population. The prevalence of aortic stenosis is only about $0.2 \%$ among adults over 50 years of age, but increases to $9.8 \%$ over 80 years of age, with an overall prevalence of $2.8 \%$ in adults older than 75 years of age (2). Even without significant stenosis, aor- tic valve sclerosis is associated with a $50 \%$ increased risk of myocardial infarction and death from cardiovas- cular causes (1-3). Once symptoms, including angina, syncope, or heart failure are present in AS, valve replacement is the only effective treatment (1). The average survival without valve replacement is no more than $1.5-2$ years after the onset of symptoms among patients with severe AS $(2,4)$.

The pathogenesis of CAVD is initiated by endothe- lial injury, followed by lipid accumulation, infiltration of inflammatory cells, degradation or increased depos- ition of the extracellular matrix (ECM), neoangiogene- sis, and extensive calcification combined with ossification (5-7). These processes are also contribu- ting factors of vascular atherosclerosis but despite pathophysiological similarities, only about $50 \%$ of patients with CAVD have clinically significant athero- sclerosis (8). To date there is no pharmacological treat- ment available to treat or even to slow down the disease progression of CAVD. Therefore, mechanisms of progression from an early inflammatory lesion to phenotype transformation of valve myofibroblasts and then to the end stage of severe valve calcification have been intensively characterized to reveal novel targets for managing the disease.

In the present review, we discuss the role of vaso- active peptides in CAVD. We summarize the current knowledge of renin-angiotensin system (RAS) counter- parts, chymase, cathepsin G, bradykinin, and its recep- tors as well as endothelin (ET), natriuretic peptide and apelin-APJ system in the pathogenesis of aortic valve calcification. In addition, we discuss potential strat-egies to target the vasoactive peptides for the devel-opment of pharmacological treatment and diagnosis to CAVD. 


\section{The renin-angiotensin system (RAS)}

During the last decades the focus of research has been changed from systemic and endocrine RAS to autocrine and paracrine effects of tissue RAS (9). Tissue RAS functions by inducing fibroblast prolifer-ation, expression of proinflammatory mediator ET-1

(10) and ECM deposition, suggesting that paracrine/ autocrine RAS may play a major role in the pathogen- esis of aortic valve stenosis. In addition to the classical RAS (renin, Ang I, angiotensin converting enzyme [ACE], Ang II, and angiotensin II receptors type 1 and 2 [AT 1 and $\mathrm{AT}_{2}$ ], newer components such as (pro)renin receptor, $A C E 2$, its product angiotensin (1-7) [Ang-(1- 7)] and its receptor Mas proto-oncogene have been recently discovered providing potential targets for pharmacological therapies. So far, RAS has been the major target for drugs in attempt to seek therapeutic strategies for patients with CAVD and several clinical trials have evaluated the effect of angiotensin receptor blockers (ARBs) and angiotensin convertase enzyme inhibitors (ACEI)s on the progression of CAVD.

\section{Angiotensin II, $A T_{1}$ and $A T_{2}$ receptors}

The functional effects of Ang II are mediated via two receptor isoforms $A T_{1}$ and $A T_{2}$. Although $A T_{1}$ shares structural homology with $A T_{2}$, they are functionally dis- tinct and differentially distributed $(11,12)$. The classical systemic effects of Ang II (vasoconstriction, cardiac hypertrophy, ECM formation, and increased release of aldosterone) are mediated via $A T_{1}$ (13). According to theory, the beneficial effects on cardiovascular system (antifibrotic effect, antihypertrophic effect, vasodilating effect and opposing the antinatriuretic effect) are medi- ated via $\mathrm{AT}_{2}$ receptor (13). Several studies have described the existence of local RAS in aortic valves (14-17). $A T_{1}$ receptor mRNA levels are described to be both increased (15) and unchanged (16) in stenotic aortic valves. These results may be explained by the interindividual variability in the abundance of the $\mathrm{AT}_{1}$ receptor in the valvular tissue since in one study $\mathrm{AT}_{1}$ receptor was detected in only less than $20 \%$ of nonste- notic valves but in $75 \%$ of stenotic valves (14). Even though a decrease in gene expression levels of $A T_{2}$ receptor was seen in $A S$ valves when compared with normal aortic valves, the $A T_{2}$-receptors were not detected by immunohistochemistry in normal or calci- fied valves (16). Ang II have been shown to promote aortic valve thickening independent of elevated blood pressure in apolipoprotein-E deficient mice (18), and induce vascular calcification in vitro and in vivo through receptor activator of nuclear factor-j $\mathrm{B}$ ligand (RANKL) system activation (19). In addition, RANKL activated RAS, especially ACE and AT1 receptor, providing RANKL as a novel therapeutic option to inhibit RAS and pre- vent vascular calcification. Previously, RANKL, a compo- nent of emerging regulatory pathway (nuclear factor- jB (RANK), RANKL, and osteoprotegerin (OPG)) for vas-cular calcification (20), has been reported to contribute to vascular calcification by decreasing the calcification inhibitor, matrix Gla protein, in vascular smooth muscle cells, and elevating bone morphogenetic protein-2 (BMP-2) expression in endothelial cells (19).

Three retrospective studies have been published according to which ARBs are useful in the treatment of AS (Table 1). Japanese Aortic Stenosis Study (JASS) showed that initiation of ARB treatment during the early stage of the CAVD may be effective in slowing the progression of AS (21), 
and in a study with hyper- tensive patients, ARB (but not ACEI) treatment was associated with slower progression of CAVD (22). In another retrospective study, the use of ARBs was asso- ciated with a lower remodelling score of stenotic aor- tic valves (23). However, the treatment with candesartan for five months in patients with clinically significant AS did not have beneficial effects on mor- tality or left ventricular mass and function (24) (Table 2). Additionally, treatment of cholesterol-fed rabbits with olmesartan has been associated with decreased macrophage infiltration and reductions in osteopontin and ACE in aortic valves (25). Unfortunately, no hemo- dynamic valvular measurements of AS progression were performed in that study (25). In addition, hemo- dynamic factors and effects of ARB fimasartan on LV remodeling is being investigated in ongoing study in patients with asymptomatic moderate to severe AS as well as effect of telmisartan and losartan in bicuspid aortic valve patients (Table 2).

Angiotensin converting enzyme (ACE), ACE2 and Mas receptor

ACE is a metalloproteinase that hydrolyzes angiotensin I into Ang II. Additionally, there are two other 


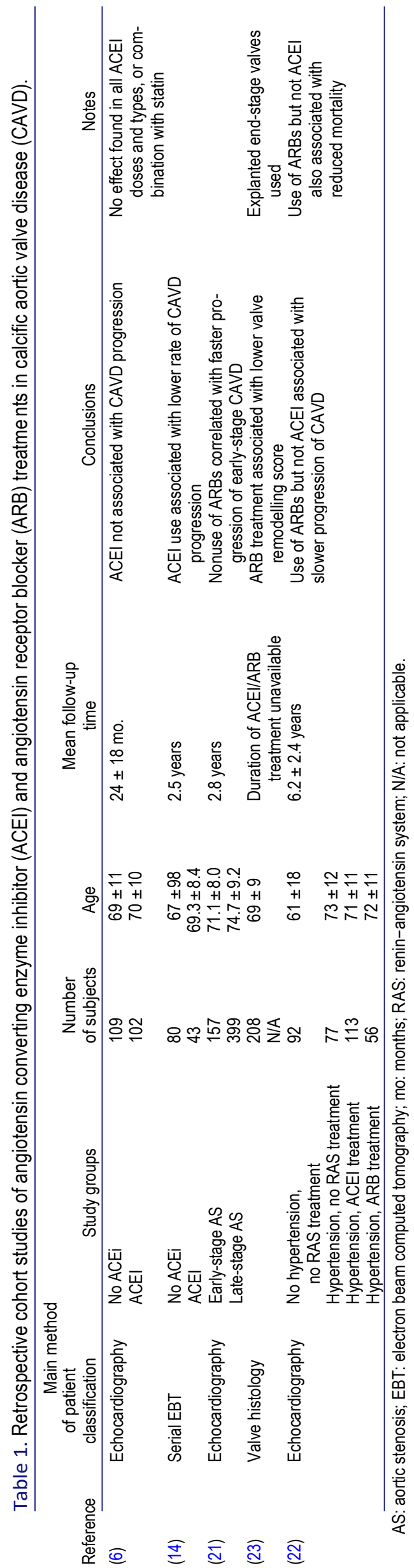

enzymes, chymase and cathepsin G, capable of increasing Ang II amounts locally in stenotic aortic valves $(15,30)$. ACE2 is thought to counteract actions of Ang II by hydrolysing Ang II to Ang-(1-7), which in turn has opposite effects to those of Ang II by mediating beneficial antifibrotic, antihypertrophic, antiproliferative and anti-inflammatory effects $(9,13,31)$.

ACE is present in aortic valvular lesions, where it colocalizes with its product, Ang II, and with retained plasma lipoproteins (14). In calcified valves, both ACE mRNA levels and protein activity of ACE are increased (15), whereas components of ACE2-Ang-(1-7) -Mas -axis were reported to be downregulated in stenotic aortic valves (17). Due to decreased ACE2 mRNA levels in stenotic valves, the disequilibrium between ACE and ACE2 expressions may play a key role in fibrocalcific process in which Ang II generation by $A C E$, chymase and cathepsin $G$ is increased $(14,15,17,30)$. Interestingly, these enzymes can also inactivate the antifibrotic bradykinin (50). Furthermore, Ang-(1-7) has antiangiogenic properties (32) suggesting that decreased production of Ang-(1-7) may, in part, contribute to the angiogenesis in fibrocalcific process. All in all, ACE inhibition may result in antiatherosclerotic effects, reduced neointimal formation and improved endothelial function and plaque stabilization (33), and ACEls are on theoretical level likely to have beneficial effects among CAVD patients (34).

There are several studies evaluating the effect of ACEls in patients of AS (Tables 1-2). Indeed, beneficial effects have been reported in a retrospective report concerning ACEl treatment and lowered aortic valve calcium (AVC) accumulation, as measured by electron beam computed tomography (35). In three clinical trials, the beneficial effects of ACEls can be explained by improved hemodynamics (26-28) (Table 2). In addition, in a recent observational study of more than 2000 patients with AS, the use of RAS inhibitors was associated with a significantly lower risk of death and other serious cardiovascular events in AS, even in patients with severe valve obstruction (36). In one prospective, double-blind, controlled trial the ramipril group showed a slower rate of progression of the AS (valve area $0.0 \mathrm{~cm} 2$ in the ramipril group vs. $-0.2 \mathrm{~cm} 2$ in the placebo arm) but without statistical significance (29). Furthermore, there is an ongoing study of effects of captopril or trandolapril on hemodynamic and functional parameters in patients with severe AS. As regards human studies, no prospective large trials of ACE have been published to date. High blood pressure can be considered as a major determinant of valvedis-ease progression, maybe through mechanical stretch-ing of 


\begin{tabular}{|c|c|c|c|c|c|c|c|}
\hline Study & Intervention & patients & Duration & CAVD status & Main outcome variables & Results & identifier \\
\hline SCOPE-ASa & Enalapril vs. placebo & 56 & $\begin{array}{l}1 \text { month ( } 3 \text { month } \\
\text { follow-up for } \\
\text { selected patients) }\end{array}$ & $\begin{array}{l}\text { Symptomatic } \\
\text { severe }\end{array}$ & $\begin{array}{l}\text { Development of hypertension, Borg } \\
\text { dyspnea index, 6-min walk distance, } \\
\text { off-target drug effects, NYHA-class } \\
\text { changes, echocardiographic } \\
\text { parameters }\end{array}$ & $\begin{array}{l}\text { Improvement in NYHA } \\
\text { class, Borg index } \\
\text { and 6-min walk dis- } \\
\text { tance. } \\
\text { Benefit greatest in } \\
\text { patients with regur- } \\
\text { gitant valve lesions }\end{array}$ & $(26)$ \\
\hline $\begin{array}{l}\text { Effects of angiotensin converting } \\
\text { enzyme inhibitors in hypertensive } \\
\text { patients with aortic valve stenosis: a } \\
\text { drug withdrawal studya }\end{array}$ & $\begin{array}{l}\text { Various ACEls, cross- } \\
\text { over design }\end{array}$ & 20 & $\begin{array}{l}\text { Not reported } \\
\text { (withdrawal } \\
\text { study) }\end{array}$ & Asymptomatic AS & Hemodynamic and functional variables & $\begin{array}{l}\text { Reduction in afterload, } \\
\text { compensated by } \\
\text { increase in trans- } \\
\text { valvular pressure } \\
\text { gradient. } \\
\text { Hemodynamic varia- } \\
\text { bles improved in } \\
\text { most hypertensive } \\
\text { patients. }\end{array}$ & (27) \\
\hline $\begin{array}{l}\text { Short-term hemodynamic effect of } \\
\text { angiotensin-converting enzyme } \\
\text { inhibition in patients with severe } \\
\text { aortic stenosis }\end{array}$ & $\begin{array}{l}\text { Trandolapril vs. } \\
\text { placebo }\end{array}$ & 44 & 8 weeks & Severe AS & $\begin{array}{l}\text { Acute hemodynamic effects of ACEI, } \\
\text { change in systemic BP, SAC, Zva, } \\
\text { NT-proBNP, exercise capacity }\end{array}$ & $\begin{array}{l}\text { Reduction in left ven- } \\
\text { tricular end systolic } \\
\text { volume and NT- } \\
\text { proBNP }\end{array}$ & (28) \\
\hline RIASa & Ramipril vs. placebo & 100 & 1 year & $\begin{array}{l}\text { Moderate or } \\
\text { severe asymp- } \\
\text { tomatic AS }\end{array}$ & $\begin{array}{l}\text { LVM, systolic velocity, progression of } \\
\text { CAVD by cardiac magnetic } \\
\text { resonance }\end{array}$ & $\begin{array}{l}\text { Reduction in LVM, pre- } \\
\text { served systolic pres- } \\
\text { sure, non-significant } \\
\text { reduction in pro- } \\
\text { gression of CAVD }\end{array}$ & (29) \\
\hline ROCK-ASa & $\begin{array}{l}\text { Candesartan vs. } \\
\text { placebo }\end{array}$ & 51 & 5 months & Severe AS & $\begin{array}{l}\text { Mortality, LV mass and function, 6-min } \\
\text { walking test, Nt-proBNP }\end{array}$ & & (24) \\
\hline ACCESS $^{b}$ & $\begin{array}{l}\text { Captopril or trandolap- } \\
\text { ril vs placebo }\end{array}$ & 64 & 8 weeks & Severe AS & $\begin{array}{l}\text { Hemodynamic and functional } \\
\text { parameters }\end{array}$ & & NCT00252317 \\
\hline $\mathrm{ALFA}^{\mathrm{b}}$ & Fimasartan vs. placebo & 100 & 1 year & $\begin{array}{r}\text { Moderate to } \\
\text { severe AS }\end{array}$ & $\begin{array}{l}\text { Change of } \mathrm{VmaxO}_{2} \text { in cardiopulmonary } \\
\text { exercise test, various hemodynamic } \\
\text { parameters, LVM, hospitalization, } \\
\text { mortality }\end{array}$ & & NCT01589380 \\
\hline BAV studyc & $\begin{array}{l}\text { Telmisartan vs. pla- } \\
\text { cebo. Parallel arm } \\
\text { tests atenolol vs. } \\
\text { placebo. }\end{array}$ & 85 & 5 years & $\begin{array}{l}\text { BAV, no CAVD at } \\
\text { baseline }\end{array}$ & $\begin{array}{l}\text { Change from baseline in ascending } \\
\text { aorta size, as evaluated by MRI; rate } \\
\text { of change in ascending aorta size } \\
\text { evaluated by (TEE) }\end{array}$ & & NCT01202721 \\
\hline $\begin{array}{l}\text { The effect of losartan in bicuspid aortic } \\
\text { valve patients. }\end{array}$ & $\begin{array}{l}\text { Losartan (open label, } \\
\text { single group) }\end{array}$ & 25 & 1 year & $\begin{array}{l}\mathrm{BAV}, \text { no CAVD at } \\
\text { baseline }\end{array}$ & Inflammatory blood markers & & NCT01390181 \\
\hline
\end{tabular}

Status of the study acompleted bunknown, and congoing

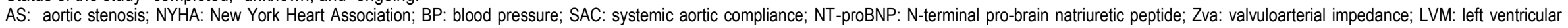
mass; BAV: bicuspid aortic valve; MRI: magnetic resonance imaging; TEE: transthoracic echocardiography.

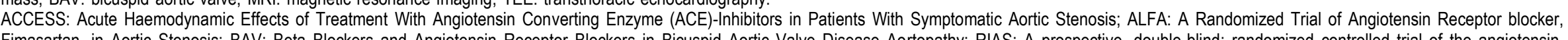

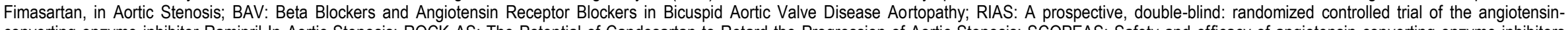

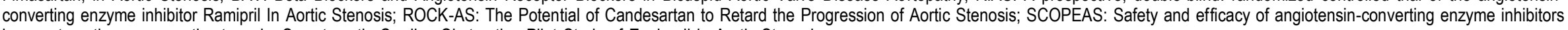
in symptomatic severe aortic stenosis: Symptomatic Cardiac Obstruction-Pilot Study of Enalapril in Aortic Stenosis. 
In addition, increased vascular afterload (ventricular wall stress) induces left ventricular hypertrophy and dysfunction, and this together with chronic valvular and vascular pressure overload is a major cause of the morbidity and mortality of CAVD (37). Thus, some beneficial effects of ACE inhibitors, and ARBs as well, on clinical outcomes in patients with AS, could be attributed to lowering of blood pressure.

There might also be differences between ACE inhib- ition and $A T_{1}$ antagonism as pharmacologic approach for calcified aortic valve disease. In several studies ACE inhibitors have modulated various components of the atherosclerotic process by inhibiting Ang II formation and by reducing breakdown of anti-fibrotic bradykinin (33). Ang II increases lipid peroxidation and oxyradical formation, stimulates the expression of proinflamma-tory genes, such as chemoattractant protein and leucocyte adhesion molecules, resulting in endothelial dysfunction $(14,15,17,30)$. In addition, Ang II induces vascular smooth-muscle proliferation (38). By favoring the balance between Ang II and bradykinin, ACEls are likely to improve endothelial function and counteract initiation and progression of atherosclerosis (33). However, quantitative differences do exist among ACEls. Ramipril and perindopril are highly lipophilic and have strong enzyme-binding capabilities; such ACE inhibitors may probably provide greater penetration into the atherosclerotic plaque in valvular location as well. Interestingly, hemodynamic retardation of AS, concomitantly with reduction in calcification, macro- phage infiltration, redox stress and improvement in endothelial function has been reported with ramipril treatment in a model of AS in New Zealand white rab- bits (39).

Both Mas and $\mathrm{AT}_{2}$-receptor mRNA levels are both significantly downregulated in stenotic aortic valves (17). Since, Ang Il-forming enzymes are upregulated and $\mathrm{AT}_{1}$-receptor protein levels are increased in sten- otic valves $(14,15)$, the downregulation of both Mas and $A_{2} T_{2}$-receptor expression $(16,17)$, via unopposed $A T_{1}$-receptor activation, may augment the profibrotic and pro-inflammatory effects of RAS. Furthermore, Mas and $\mathrm{AT}_{2}$-receptor activation induce eNOS activation (40), and mutant mice lacking the Mas exhibit impaired endothelial function, decreased NO produc- tion and lower endothelial NO synthase (eNOS) expres- sion (40). In humans, expression of Mas receptor is mainly restricted to endothelial cells (41), so Mas, along with the $\mathrm{AT}_{2}$, may contribute to the downregu- lation of eNOS and endothelial dysfunction in calcific aortic valve disease as well. Moreover, the first select-ive $\mathrm{AT}_{2}$ agonist compound $21(\mathrm{C} 21)$ has been shown to have anti-inflammatory effects $(13,42)$ so it would be interesting to see whether $\mathrm{AT}_{2}$ agonism could pre- vent inflammatory response related to disease progression of AS.

Renin, prorenin and (pro)renin receptor

Renin is a proteolytic enzyme synthesized and secreted as an inactive proenzyme, prorenin. The only known substrate for renin is angiotensinogen, which is cleaved by renin to form angiotensin I (43). A specific human renin receptor, $(P) R R$, binds both prorenin and renin and shows a dual function. First, binding of pro- renin to (P)RR leads to its activation and to generation of Ang II locally (43). Secondly, binding of renin or pro- renin to (P)RR results in the activation signaling path- ways associated to profibrotic and proliferative actions as well as endothelial cell function and neovasculariza- tion, independent of Ang II production (43-45).

Both renin and prorenin gene expression have been reported to be downregulated in stenotic aortic valves compared to normal valves, whereas no change in (P)RR mRNA levels has been noted (17). Instead, a reduced amount of (P)RR positivity was seen in the valvular endothelial cells of stenotic valves but more in neovessels, consistent with proangiogenic effect of (P)RR (17). Prorenin receptor ((P)RR) is the first counter- part receptor of tissue 
RAS, therefore (P)RR antagonism as a strategy would lead lowered activity of whole RAS cascade downwards. One important aspect of (P)RR is that it appears to be a vital component of the wnt/b- catenin pathway (46). With its component, low-density lipoprotein receptor-related protein 5 (Lrp5), this path- way seems to be upregulated in the valvular tissue of rabbit CAVD (47), and is a known regulator of osteo- genic differentiation (48). These raise the intriguing possibility that inhibition of (P)RR may also disturb the wnt/Lrp5/b-catenin-mediated osteogenic differentiation of valvular interstitial cells.

\section{Bradykinin and bradykinin receptors}

Kinin peptides act via two types of kinin receptors: the bradykinin B1 receptor (B1R) and the bradykinin B2 receptor (B2R). The cardioprotective effect of stimula- tion of B2R trigger the production of nitric oxide (NO) and exerts antiproliferative and anti-hypertrophic effects on myocytes and fibroblasts (49). In stenotic valves, increased expression of $B 1 R$ and B2R has been reported (50). Furthermore, exposure to tumor necrosis factor-a (TNFa) increased gene expression of B1R and B2Rin valvular cell culture environment (50). Ang Il generation by ACE, chymase and cathepsin $\mathrm{G}$ is increased in AS valves $(14,15,17,30)$. Interestingly, these enzymes can also inactivate the antifibrotic bradykinin $(31,51)$. Conversely, bradykinin counteracts the nega- tive action of Ang II and improves endothelial function by increasing expression and activity of the constitu- tive NO synthase (50). Bradykinin also inhibits the expression of monocytes and adhesion molecules (50), and has an antiproliferative effect $(49,52)$. In addition, in inflammatory conditions, bradykinin receptors B1 and B2 can couple to activate NF-kB signaling through Akt and/or ERK1/2 pathways, which leads to inhibition of osteoblastic differentiation with subsequent activa- tion of osteoclast formation (53). Consequently, brady- kinin receptor specific agonists and/or antagonists could be therapeutic agents also in development of CAVD. Additionally, neutral endopeptidase (NEP or neprilysin), another enzyme capable to degrading bradykinin, is upregulated in stenotic valves (50). These findings suggest that downregulation of brady- kinin contributes to the shift of balance between fibrotic and antifibrotic factors promoting fibrosis in calcific aortic valve stenosis (17). Consequently, inhibit- ing ACE, chymase, cathepsin G, and NEP that all con- tribute in producing Ang II by inhibiting bradykinin might lead to success as pharmacological CAVD therapy.

\section{Endothelin and endothelin receptors}

Four structurally different endothelin (ET) isoforms have been described (i.e., ET-1, ET-2, ET-3, ET-4). Mature ET-1 is formed from pre-pro-ET-1 via an inter-mediate big ET-1 by a family of endothelin converting enzymes (ECEs) and other enzymes such as chymases, and endopeptidases (54). The biological effects of ET-1 are mediated by $\mathrm{ET}_{\mathrm{A}}$ and $\mathrm{ET}_{\mathrm{B}}$ receptors, both of which are expressed in aortic valves. $\mathrm{ET}_{\mathrm{A}}$ receptor expression is increased in stenotic valves whereas no changes in $\mathrm{ET}_{\mathrm{B}}$ expression was reported (55). In addition, increased plasma big ET-1 levels have been reported in patients with AS (56). In stenotic aortic valves, ET-1 protein is increased without increase in ET-1 mRNA levels, likely reflecting $E T_{B}$ receptor mediated up-take of ET-1 from circulation (55). However, the levels of $E T_{B}$ receptors were similar between control and sten- otic valves in the recent study (55). Another possibility would be the changes in the degradation of ET-1. This seems, however, unlikely due to the increase in NEP activity in stenotic aortic valves (15). The pathophysio- logical significance of increased ET-1 peptide levels in aortic valve stenosis may be further 
enhanced by the concomitant upregulation of $\mathrm{ET}_{\mathrm{A}}$ receptor gene (55). Since, continued stimulation of cells with agonists gen- erally result in a down-regulation of receptors, one would expect either $\mathrm{ET}_{\mathrm{A}}$ or $\mathrm{ET}_{\mathrm{B}}$ or both receptors to be down-regulated due to higher ET-1 peptide levels in stenotic valves. So it is possible that the net effect of ET-1 can be considered to be determined by recep- tor localization and the balance between $\mathrm{ET}_{\mathrm{A}}$ and $\mathrm{ET}_{\mathrm{B}}$ receptors (57). As increased $\mathrm{ET}-1$ and $\mathrm{ET}_{\mathrm{A}}$ protein levels have been documented in stenotic aortic valves (55), particularly $\mathrm{ET}_{\mathrm{A}}$ receptor antagonism could potentially reduce the actions of ET-1 and even slow down the development of CAVD.

Interestingly, ET-1 was found to regulate calcifica- tion in both in vivo and in cultured vascular smooth muscle cells (58). Moreover, administration of bosentan attenuated vascular calcification induced by vitamin D3 plus administration of nicotine in rats, but whether ET-1 has a role in development in CAVD is not known (58). Experimental studies have established a role for vitamin $D$ metabolites in pathways that are integral to cardiovascular function and disease, including inflam- mation, thrombosis, and the renin-angiotensin system and low levels of vitamin D are associated with cardio- vascular diseases (59). Interestingly, VDR deficiency and diets low in vitamin $\mathrm{D}$ promote aortic valve and aortic vessel calcification in the $\mathrm{VDR}^{-1-}$ and $\mathrm{LDLR}^{-1}$ - mouse models (60). The vascular calcification in this

study was associated with an up-regulation of osteo- blast transcription factors which could have triggered the differentiation of vascular cells into osteoblast-like cells (60).

The effect of dualistic $\mathrm{ET}_{\mathrm{A}} / \mathrm{ET}_{\mathrm{B}}$ inhibition by tezosen- tan on $\mathrm{ET}-1$ uptake was recently studied in cultured human aortic valve tissue explants (61). Promisingly, tezosentan reduced the uptake of ET-1 to valve tissue more effectively in sclerotic aortic valve cusp explants than in macroscopically normal sections (61). However, it remains to be determined whether ET receptor antagonists might have beneficial effects in slowing down the progression of AS. Experimentally, $\mathrm{ET}_{\mathrm{A}}$ receptor blockade prevents endothelial dysfunction and structural vascular changes in atherosclerosis (54). On the other hand, the vasodilating and blood pres- sure lowering properties of ET receptor antagonists might present a clinical problem in AS. In patients with heart failure, $\mathrm{ET}_{\mathrm{A}}$ receptor antagonists (e.g., tezo- sentan) have controversial effects, although neurohor- mones and natriuretic peptides decreased favorably by treatment (62). In addition to ET-1, NO signaling path- way is involved in aortic valve calcification since both eNOS and iNOS are expressed in human aortic valves, and eNOS gene expression is downregulated in sten-otic valves (55). Thus, imbalance between $\mathrm{ET}_{\mathrm{A}}$ and $\mathrm{ET}_{\mathrm{B}}$ receptors is potentiated by downregulated eNOS gene expression, similarly to endothelial dysfunction in ath- erosclerosis (57).

\section{Apelin - APJ system}

Apelin, an adipokine, and its receptor APJ are expressed in several tissues including the heart, vascu- lature and aortic valves $(16,63)$. The proposed cardio- vascular effects of the apelin-APJ system are opposite to the effects of the RAS. ACE2, breaking down Ang II to Ang (1-7), acts on apelin as well, suggesting a dynamic interaction between apelin and Ang II path- ways (64). Interestingly, non-activated APJ suppresses $\mathrm{AT}_{1}$, whereas apelin-activated APJ acts conversely (65).

In stenotic aortic valves, there are increased mRNA and protein levels of apelin which are potented by the upregulation on APJ gene (16). Therefore, the upregu- lated apelin-APJ axis may also act as a compensatory mechanism ameliorating the harmful effects of $\mathrm{AT}_{1}$ receptor activation in the pathogenesis of aortic valve stenosis. In endothelial cells, apelin is expressed pri- marily in cells at sites of active vascular growth (66), and APJ receptor may play an 
important role in angio- genesis (67). In vitro, apelin promotes chemotaxis in human endothelial cells (68), a wellestablished phe- nomenon in the plaque formation in stenotic aortic valves (69). In addition, apelin has been reported to stimulate proliferation and to suppress apoptosis of mouse osteoblastic cell line (70), and importantly, ape- lin was shown to attenuate the osteoblastic differenti- ation of aortic valve interstitium cells (VICs) via the extracellular signalregulated kinase (ERK) and phos- phatidylinositol-3 kinase (PI3-K)/Akt pathway (71). Consequently, APJ receptor antagonists might be beneficial in the treatment of aortic valve stenosis by suppressing chemotaxis, angiogenesis and osteoblast activity. Apelin can also block a number of Ang II-related pathological processes associated with atherosclerosis (72) and inhibit fibrosis (73). It could be negatively regulated by miR125b (74), which are upregulated in stenotic valves (75). So far, there are no drugs targeting the apelin/APJ system available. By development of suitable agonists/antagonists, it will be intriguing to evaluate the impact of drug treatment targeting apelin/APJ system on CAVD pathology.

\section{Natriuretic peptides}

Natriuretic peptide family consists of three members, namely ANP (atrial natriuretic peptide), BNP (B-type natriuretic peptide) and CNP (C-type natriuretic pep- tide), whose biological effects are mediated by specific cell surface guanylate cyclase (GC) -linked receptors. ANP, BNP and CNP are produced as pro-forms and they are converted into mature peptides by proteolytic processing of the respective precursor molecules. Corin has been identified as a proANP- and proBNP- converting enzyme (76), whereas furin processes proCNP to its mature form (77).

All natriuretic peptides, their receptors as well as their processing enzymes are expressed in aortic valves (78). The CNP system, i.e., CNP, furin and target receptor GC-B, has been reported to be down-regu- lated in stenotic valves, when compared with non-cal- cified aortic valves while no changes in ANP and BNP were seen (78). Degradation of CNP does not exist only via target receptor GC-B or clearance receptor natriuretic peptide receptor-C (NPR-C), but via proteo- lytic processing by NEP, which has been reported to be up regulated in AS both in mRNA and protein level (50).

Interestingly, CNP has a role in the bone growth $(79,80)$, and it seems to inhibit vascular calcification (81), fibrosis (82) and inflammation (83), which sug- gests its downregulation may be a contributing factor in several underlying processes of CAVD. In one study, CNP attenuated calcification partly via a CGMP/protein kinase $G$ pathway both in rat calcified aortas and cul- tured vascular smooth muscle cells affecting protein levels of osteopontin and bone morphogenetic protein (81). In addition, CNP has been shown to suppress cal- cified aggregate formation in (VICs) in vitro, as well as inhibit differentiation of VICs to osteoclasts and myofi- broblasts when cultured under osteogenic and myofi- brogenic conditions, respectively (84). Furthermore, CNP expression was stimulated by simvastatin in VICs grown in myofibrogenic conditions, whereas small interfering RNA knockdown of NPRP-C significantly reduced the antifibrotic effect of simvastatin, suggest- ing that statins may act in part via CNP/NPR-B auto- crine/paracrine signaling in the aortic valve (84).

The studies of mice with endothelial-specific dele-

tion of CNP (ecCNP KO mouse) indicated that endo- thelium derived CNP could contribute to reversing the development of atherosclerotic lesions (85) and inter- vention with endothelium derived CNP could amelior- ate fibrosis by reducing the activity and release of several matrix metalloproteinases (MMPs), including MMP-9, (86), whose mRNA expression and activation is increased in calcific valves (87). However, if CNP agon-ism with valvular targeted delivery would be consid- ered as pharmacological intervention, valvular target receptors should be 
available in large scale in order to mediate beneficial effects of CNP.

An intriguing pharmacological approach would also be to investigate potential inhibitors to NEP or other

Table 3. Expression of vasoactive peptides in calcified aortic valves (vs normal) and their localization in calcified valves/normal valves.

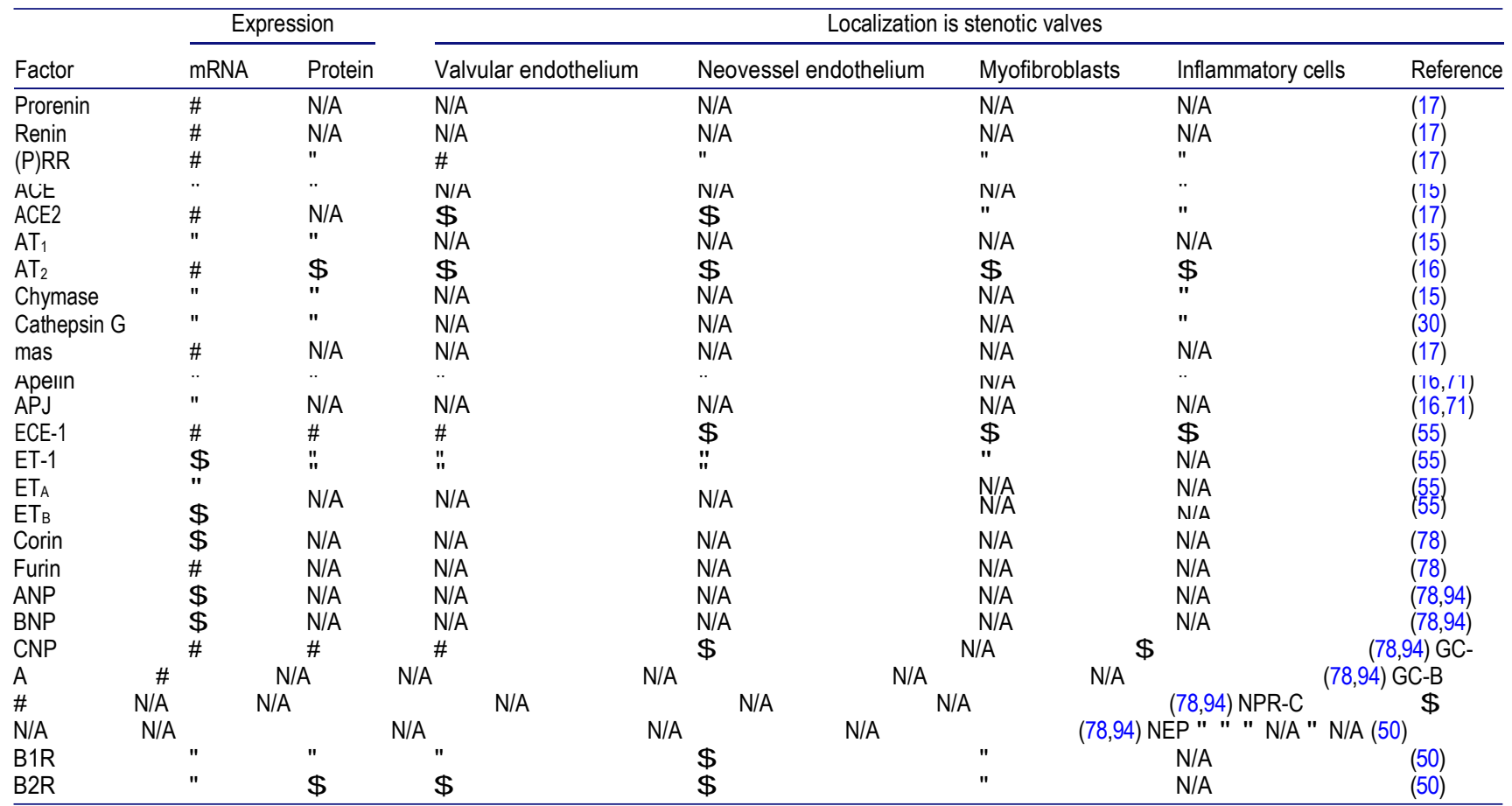

Upregulated ("), downregulated (\# or unchanged (\$gene/protein expression in stenotic aortic valves compared to uncalcified valves. N/A, no studies performed to date.

Angiotensin converting enzyme (ACE) and type 2 (ACE2); angiotensin type 1 ( $A T_{1}$ ) and type $2\left(\mathrm{AT}_{2}\right)$ receptor; $A P J$ : apelin receptor; atrial (ANP) and B-type natriuretic peptide (BNP); bradykinin B1 (B1R) and B2 (B2R) receptor; CNP (C-type natriuretic peptide); ECE-1: endothelin converting enzyme 1; ET-1: endo- thelin1; endothelin receptor $A\left(E T_{A}\right)$ and $B\left(E T_{B}\right) ; G C$ : guanylyl cyclase; NEP: neutral endopeptidase; natriuretic peptide receptor $C$ (NPR-C); (P)RR: renin receptor.

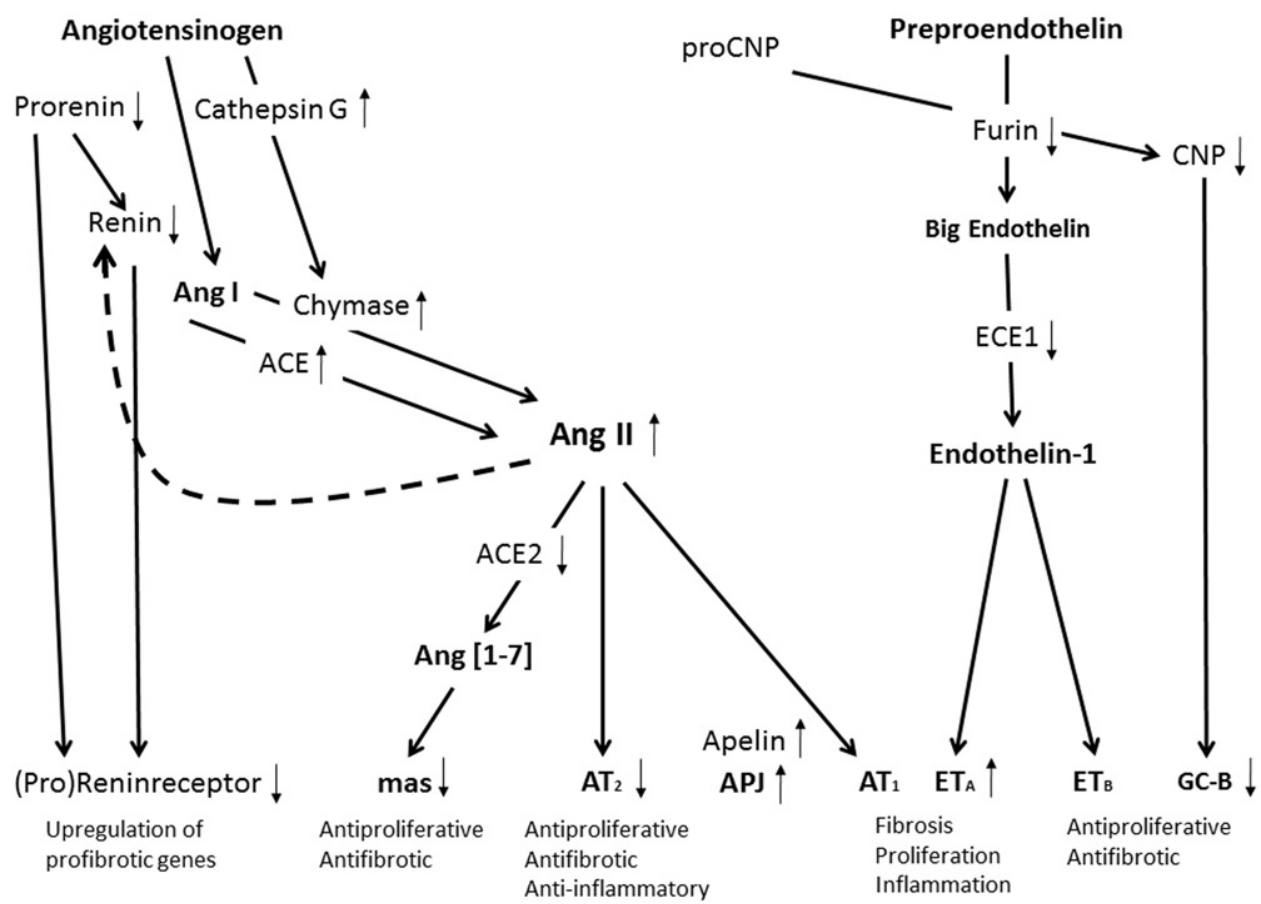

Figure 1. Vasoactive peptides in calcific aortic valve disease. A schematic illustration summarizing peptides involved in comprehensive shift in the balance of valvular RAS components towards"activated ACE/Ang曲AT 1 -receptor-med inflammation in AS. Black arrows show reported upregulated ( ), downregulated ( ) or unchanged ( ) gene expression in stenotic aortic valves. 
CNP-degrading enzymes, as is the case with LCZ696 (sacubitril/valsartan). Combined neprilysin inhibition with valsartan (sacubitril $p$ valsartan) seems to be inter- esting dualistic strategy with solid theory of benefits of ARB as well as prolonging effect of natriuretic pepti- des. Sacubitril is a first-in-class angiotensin receptor neprilysin inhibitor, converted by esterases to LBQ657, which inhibits neprilysin, the enzyme responsible for the degradation of the natriuretic peptides and many other vasoactive peptides (88). The neprilysin inhib- ition in combination with ARB therapy could theoretic- ally improve prognosis in patients with CAVD due to its beneficial effects on congestive heart failure (89).

Finally, BNP is the most investigated circulating bio- marker for AS, and it has been shown to be related to severity and functional status of the disease $(90,91)$. In a recent study, BNP clinical activation was detected as a predictor of long-term mortality in patients with moderate or severe AS (92), whereas in a large pro-spective cohort NT-proBNP had a poor diagnostic value for severe symptomatic AS in elderly patients (91). Consequently, BNP has not yet been shown to provide sufficient incremental value in risk stratifica- tion in managing patients with AS $(1,93)$.

\section{Conclusions}

Several components of vasoactive peptide systems are expressed in aortic valves with significant up/downre- gulation in CAVD (Table 3). So far, local RAS is the most studied vasoactive system, and the expression of its components may contribute to ACE/Angll/AT1- receptor-mediated fibrosis, proliferation and inflamma- tion in AS (Figure 1). Clinical trials have shown benefi- cial effects in AS patients managed with ARB but not with ACEI (Tables 1-2). Although vasoactive factors have been intensively studied at the molecular level, there is lack of pharmacological agents to manipulate these systems. Nevertheless, renin, (P)RR, and endothe- lin (ETA/ETB) receptor antagonists should be studied in more detail in prospective clinical studies in CAVD patients.

\section{Disclosure statement}

T.P. is an employee of MSD Finland.

\section{Funding}

This study was supported by the Academy of Finland Center of Excellence Funding (H.R.) and the grants 266661 (H.R.), 276747 (J.R.) and 284504 (J.R.), Sigrid Juselius Foundation (H.R), the Finnish Foundation for Cardiovascular Research (J.R., H.R., P.O.), Paavo Nurmi Foundation, Ida Montin 
Foundation (P.O.), Aarne Koskelo Foundation and Orion Farmo's research foundation.

\section{References}

1. Nishimura RA, Otto CM, Bonow RO, Carabello BA, Erwin JP, 3rd, Guyton RA, et al. 2014 AHA/ACC guide- line for the management of patients with valvular heart disease: executive summary. A Report of the American College of Cardiology/American Heart Association Task Force on Practice Guidelines. J Am Coll Cardiol. 2014;63:2438-88.

2. Otto CM, Prendergast B. Aortic-valve stenosis-from patients at risk to severe valve obstruction. N Engl J Med. 2014;371:74456.

3. Jander N, Minners J, Holme I, Gerdts E, Boman K, Brudi P, et al. Outcome of patients with low-gradient severe aortic stenosis and preserved ejection fraction. Circulation. 2011;123:887-95.

4. Aronow WS. Valvular aortic stenosis in the elderly. Cardiol Rev. 2007;15:217-25.

5. Otto CM, Kuusisto J, Reichenbach DD, Gown AM, O'Brien KD. Characterization of the early lesion of 'degenerative' valvular aortic stenosis. Histological and immunohistochemical studies. Circulation. 1994;90:844-53.

6. Rosenhek R, Zilberszac R, Schemper M, Czerny M, Mundigler G, Graf S, et al. Natural history of very severe aortic stenosis. Circulation. 2010;121:151-6.

7. Dweck MR, Boon NA, Newby DE. Calcific aortic sten- osis: a disease of the valve and the myocardium. J Am Coll Cardiol. 2012;60:1854-63.

8. Qian J, Chen Z, Ge J, Ma J, Chang S, Fan B, et al. Relationship between aortic valve calcification and the severity of coronary atherosclerotic disease. J Heart Valve Dis. 2010;194:466-70.

9. Santos RA, Ferreira AJ, Verano-Braga T, Bader M. Angiotensin-converting enzyme 2, angiotensin-(1-7) and Mas: new players of the renin-angiotensin system. J Endocrinol. 2013;216:R1-17.

10. Rossi GP, Sacchetto A, Cesari M, Pessina AC. Interactions between endothelin-1 and the renin-angiotensin-aldos- terone system. Cardiovasc Res. 1999;43:300-7.

11. Unger T, Chung O, Csikos T, Culman J, Gallinat S, Gohlke P, et al. Angiotensin receptors. J Hypertens Suppl. 1996;14:S95S103.

12. Kim S, Iwao H. Molecular and cellular mechanisms of angiotensin II-mediated cardiovascular and renal dis- eases. Pharmacol Rev. 2000;52:11-34.

13. Steckelings UM, Paulis L, Namsolleck P, Unger T. AT2 receptor agonists: hypertension and beyond. Curr Opin Nephrol Hypertens. 2012;21:142-6.

14. O'Brien KD, Shavelle DM, Caulfield MT, McDonald TO, Olin-Lewis K, Otto CM, et al. Association of angiotensin-converting enzyme with low-density lipo- protein in aortic valvular lesions and in human plasma. Circulation. 2002;106:2224-30.

15. Helske S, Lindstedt KA, Laine M, Mayranpaa M, Werkkala K, Lommi J, et al. Induction of local angioten- sin II-producing systems in stenotic aortic valves. J Am Coll Cardiol. 2004;44:1859-66.

16. Peltonen T, Napankangas J, Vuolteenaho $\mathrm{O}$, Ohtonen $\mathrm{P}$, Soini $\mathrm{Y}$, Juvonen $\mathrm{T}$, et al. Apelin and its receptor APJ in human aortic valve stenosis. J Heart Valve Dis. 2009;18:644-52.

17. Peltonen T, Napankangas J, Ohtonen P, Aro J, Peltonen J, Soini Y, et al. (Pro)renin receptors and angiotensin converting enzyme 2/angiotensin-(1-7)/ Mas receptor axis in human aortic valve stenosis. Atherosclerosis. 2011;216:35-43.

18. Fujisaka T, Hoshiga M, Hotchi J, Takeda Y, Jin D, Takai S, et al. Angiotensin II promotes aortic valve thickening independent of elevated blood pressure in apolipoprotein-E deficient mice. Atherosclerosis. 2013;226:82-7.

19. Osako MK, Nakagami H, Shimamura M, Koriyama H, Nakagami F, Shimizu H, et al. Cross-talk of receptor activator of nuclear factor-j $\mathrm{B}$ ligand signaling with renin-angiotensin system in vascular calcification. Arterioscler Thromb Vasc Biol. 2013;33:1287-96.

20. Ndip A, Wilkinson FL, Jude EB, Boulton AJ, Alexander MY. RANKL-OPG and RAGE modulation in vascular cal- cification and diabetes: novel targets for therapy. Diabetologia. 2014;57:2251-60.

21. Yamamoto K, Yamamoto H, Yoshida K, Kisanuki A, Hirano Y, Ohte N, et al. Prognostic factors for progres- sion of early- and late-stage calcific aortic valve disease in Japanese: the Japanese Aortic Stenosis Study (JASS) Retrospective Analysis. Hypertens Res. 2010;33:269-74.

22. Capoulade R, Clavel MA, Mathieu P, Cote N, Dumesnil JG, Arsenault M, et al. Impact of hyperten- sion and reninangiotensin system inhibitors in aortic stenosis. Eur J Clin Invest. 2013;43:1262-72.

23. Cote N, Couture C, Pibarot P, Despres JP, Mathieu P. Angiotensin receptor blockers are associated with a lower remodelling score of stenotic aortic valves. Eur JClin Invest. 2011;41:1172-9.

24. Helske-Suihko S, Laine M, Lommi J, Kaartinen M, Werkkala K, Kovanen PT, et al. Is blockade of the Renin-Angiotensin system able to reverse the structural and functional remodeling of the left ventricle in severe aortic stenosis? J Cardiovasc Pharmacol. 2015;65:233-40.

25. Arishiro K, Hoshiga M, Negoro N, Jin D, Takai S, Miyazaki M, et al. Angiotensin receptor-1 blocker inhib- its atherosclerotic changes and endothelial disruption of the aortic valve in hypercholesterolemic rabbits. J Am Coll Cardiol. 2007:49:1482-9.

26. Chockalingam A, Venkatesan S, Subramaniam T, Jagannathan V, Elangovan S, Alagesan R, et al. Safety and efficacy of angiotensin-converting enzyme inhibi- tors in symptomatic severe aortic stenosis: symptom- atic cardiac obstruction-pilot study of enalapril in aortic stenosis (SCOPE-AS). Am Heart J. 2004;147:E19.

27. Jimenez-Candil J, Bermejo J, Yotti R, Cortina C, Moreno M, Cantalapiedra JL, et al. Effects of angiotensin converting enzyme inhibitors in hypertensive patients with aortic valve stenosis: a drug withdrawal study. Heart. 2005;91:1311-18. 
28. Dalsgaard M, Iversen K, Kjaergaard J, Grande P, Goetze JP, Clemmensen P, et al. Short-term hemo- dynamic effect of angiotensin-converting enzyme inhibition in patients with severe aortic stenosis: a pla- cebo-controlled, randomized study. Am Heart J.2014;167:226-34.

29. Bull S, Loudon M, Francis JM, Joseph J, Gerry S, Karamitsos TD, et al. A prospective, double-blind, randomized controlled trial of the angiotensin-convert- ing enzyme inhibitor ramipril in aortic stenosis (RIAS trial). Eur Heart J Cardiovasc Imaging. 2015;16:834-41.

30. Helske S, Syvaranta S, Kupari M, Lappalainen J, Laine M, Lommi J, et al. Possible role for mast cell- derived cathepsin G in the adverse remodelling of stenotic aortic valves. Eur Heart J. 2006;27:1495-504.

31. Paul M, Poyan Mehr A, Kreutz R. Physiology of local renin-angiotensinsystems. Physiol Rev. 2006;86:747-803.

32. Machado RD, Santos RA, Andrade SP. Mechanisms of angiotensin-(1-7)-induced inhibition of angiogenesis. Am J Physiol Regul Integr Comp Physiol. 2001;280:R994-R1000.

33. Fox KM. European trial on reduction of cardiac events with perindopril in stable coronary artery disease investigators. Efficacy of perindopril in reduction of cardiovascular events among patients with stable cor- onary artery disease: randomised, double-blind, pla-cebo-controlled, multicentre trial (the EUROPA study). Lancet. 2003;3629386:782-8.

34. Elder DH, McAlpine-Scott V, Choy AM, Struthers AD, Lang CC. Aortic valvular heart disease: is there a place for angiotensinconverting-enzyme inhibitors? Expert Rev Cardiovasc Ther. 2013;11:107-14.

35. O'Brien KD, Probstfield JL, Caulfield MT, Nasir K, Takasu J, Shavelle DM, et al. Angiotensin-converting enzyme inhibitors and change in aortic valve calcium. Arch Intern Med. 2005;165:858-62.

36. Nadir MA, Wei L, Elder DH, Libianto R, Lim TK, Pauriah M, et al. Impact of renin-angiotensin system blockade therapy on outcome in aortic stenosis. J Am Coll Cardiol. 2011;58:570-6.

37. Lindman BR, Bonow RO, Otto CM. Current manage- ment of calcific aortic stenosis. Circ Res. 2013;113:223-37.

38. Stoll M, Steckelings UM, Paul M, Bottari SP, Metzger R, Unger T. The angiotensin AT2-receptor mediates inhib- ition of cell proliferation in coronary endothelial cells. J Clin Invest. 1995;95:651-7.

39. Ngo DT, Stafford I, Sverdlov AL, Qi W, Wuttke RD, Zhang Y, et al. Ramipril retards development of aortic valve stenosis in a rabbit model: mechanistic consider- ations. Br J Pharmacol. 2011;162:722-32.

40. Alenina N, Xu P, Rentzsch B, Patkin EL, Bader M. Genetically altered animal models for Mas and angio- tensin-(1-7). Exp Physiol.2008;93:528-37.

41. Vaajanen $A$, Kalesnykas $G$, Vapaatalo $H$, Uusitalo $H$. The expression of mas-receptor of the renin-angiotensin system in the human eye. Graefes Arch Clin Exp Ophthalmol. 2015;253:1053-9.

42. Wan Y, Wallinder C, Plouffe B, Beaudry $H$, Mahalingam AK, Wu X, et al. Design, synthesis, and biological evaluation of the first selective nonpeptide AT2 receptor agonist. J Med Chem. 2004;47:5995-6008.

43. Nguyen G, Delarue F, Burckle C, Bouzhir L, Giller T, Sraer JD. Pivotal role of the renin/prorenin receptor in angiotensin II production and cellular responses to renin. J Clin Invest. 2002;109:1417-27.

44. Satofuka S, Ichihara A, Nagai N, Noda K, Ozawa Y, Fukamizu A, et al. (Pro)renin receptor promotes chor- oidal neovascularization by activating its signal trans- duction and tissue renin-angiotensin system. Am JPathol. 2008;173:1911-8.

45. Uraoka M, Ikeda K, Nakagawa Y, Koide M, Akakabe Y, Nakano-Kurimoto R, et al. Prorenin induces ERK activa- tion in endothelial cells to enhance neovascularization independently of the renin-angiotensin system. Biochem Biophys Res Commun. 2009;390:1202-7.

46. Cruciat CM, Ohkawara B, Acebron SP, Karaulanov E, Reinhard C, Ingelfinger D, et al. Requirement of prore- nin receptor and vacuolar H-ATPase-mediated acidifi- cation for Wnt signaling. Science. 2010;327:459-63.

47. Rajamannan NM, Subramanłom M, Caira F, Stock SR, Spelsberg TC. Atorvastatin inhibits hypercholesterol- emia-induced calcification in the aortic valves via the Lrp5 receptor pathway. Circulation. 2005;112:1229-34. 9:

48. Gong Y, Slee RB, Fukai N, Rawadi G, Roman-Roman S, Reginato AM, et al. LDL receptor-related protein 5 (LRP5) affects bone accrual and eye development. Cell. 2001;107:513-23.

49. McAllister BS, Leeb-Lundberg F, Olson MS. Bradykinin inhibition of EGF- and PDGF-induced DNA synthesis in human fibroblasts. Am J Physiol. 1993;265:C477-84.

50. Helske S, Laine M, Kupari M, Lommi J, Turto H, Nurmi L, et al. Increased expression of profibrotic neu- tral endopeptidase and bradykinin type 1 receptors in stenotic aortic valves. Eur Heart J. 2007;28:1894-903.

51. Ferrario CM. New physiological concepts of the renin- angiotensin system from the investigation of precur-sors and products of angiotensin I metabolism. Hypertension. 2010;55:445-52.

52. Morissette G, Houle S, Gera L, Stewart JM, Marceau F. Antagonist, partial agonist and antiproliferative actions of B-9870 (CU201) as a function of the expression and density of the bradykinin B1 and B2 receptors. Br JPharmacol. 2007;150:369-79.

53. Srivastava S, Sharma K, Kumar N, Roy P. Bradykinin regulates osteoblast differentiation by Akt/ERK/NFjB signaling axis. J Cell Physiol.2014;229:2088-105.

54. Barton M, Traupe T, Haudenschild CC. Endothelin, hypercholesterolemia and atherosclerosis. Coron Artery Dis. 2003;14:47790.

55. Peltonen $T$, Taskinen $P$, Napankangas J, Leskinen $H$, Ohtonen $P$, Soini $Y$, et al. Increase in tissue endothelin- 1 and ETA receptor levels in human aortic valve sten- osis. Eur Heart J. 2009;30:242-9.

56. Bergler-Klein J, Klaar U, Heger M, Rosenhek R, Gabriel H, Binder T, et al. Big endothelin-1 is not a pre- dictor in aortic stenosis, but is related to arterial blood pressure. Int J Cardiol. 2006;113:174-80. Bohm F, Pernow J. The importance of endothelin-1 for vascular dysfunction in cardiovascular disease. Cardiovasc Res. 2007;76:8-18.

57. Wu SY, Zhang BH, Pan CS, Jiang HF, Pang YZ, Tang CS, et al. Endothelin-1 is a potent regulator in vivo in vas- cular calcification and in vitro in calcification of vascu- lar smooth muscle cells. Peptides. 2003;24:1149-56.

58. Norman PE, Powell JT. Vitamin D and cardiovascular disease. Circ Res. 2014;114:379-93. 
59. Schmidt N, Brandsch C, K€hne H, Thiele A, Hirche F,

Stangl Gl. Vitamin D receptor deficiency and low vita- min D diet stimulate aortic calcification and osteogenic key factor expression in mice. PLoS One. 2012;7:e35316.

60. Leskelá HV, Vuolteenaho O, Koivula MK, Taskinen P,

Ruskoaho H, Peltonen T, et al. Tezosentan inhibits uptake of proinflammatory endothelin-1 in stenotic aortic valves. J Heart Valve Dis. 2012;211:23-30.

61. Anand I, McMurray J, Cohn JN, Konstam MA, Notter T, Quitzau K, et al. Long-term effects of darusentan on left-ventricular remodelling and clinical outcomes in the EndothelinA Receptor Antagonist Trial in Heart Failure (EARTH): randomised, double-blind, placebo- controlled trial. Lancet.2004;364:347-54.

62. Yu XH, Tang ZB, Liu LJ, Qian H, Tang SL, Zhang DW, et al. Apelin and its receptor APJ in cardiovascular dis- eases. Clin Chim Acta. 2014;428:1-8.

63. Vickers C, Hales P, Kaushik V, Dick L, Gavin J, Tang J, et al. Hydrolysis of biological peptides by human angiotensinconverting enzyme-related carboxypepti- dase. J Biol Chem. 2002;277:14838-43.

64. Sun X, lida S, Yoshikawa A, Senbonmatsu R, Imanaka K, Maruyama K, et al. Non-activated APJ suppresses the angiotensin II type 1 receptor, whereas apelin-acti- vated APJ acts conversely. Hypertens Res. 2011;34:701-6.

65. Saint-Geniez M, Masri B, Malecaze F, Knibiehler B, Audigier Y. Expression of the murine msr/apj receptor and its ligand apelin is upregulated during formation of the retinal vessels. Mech Dev. 2002;110:183-6.

66. Goidescu CM, Vida-Simiti LA. The apelin-APJ system in the evolution of heart failure. Clujul Med. 2015;88:3-8.

67. Cox CM, D'Agostino SL, Miller MK, Heimark RL, Krieg PA. Apelin, the ligand for the endothelial G-pro- tein-coupled receptor, APJ, is a potent angiogenic fac- tor required for normal vascular development of the frog embryo. Dev Biol. 2006;296:177-89.

68. Helske S, Oksjoki R, Lindstedt KA, Lommi J, Turto H, Werkkala K, et al. Complement system is activated in stenotic aortic valves. $\quad$ Atherosclerosis. 2008;196:190-200.

69. Eyries M, Siegfried G, Ciumas M, Montagne K, Agrapart M, Lebrin F, et al. Hypoxia-induced apelin expression regulates endothelial cell proliferation and regenerative angiogenesis. Circ Res. 2008;103:432-40.

70. Yuan ZS, Zhou YZ, Liao XB, Luo JW, Shen KJ, Hu YR, et al. Apelin attenuates the osteoblastic differentiation of aortic valve interstitial cells via the ERK and PI3-K/ Akt pathways. Amino Acids. 2015;47:2475-82.

71. Chun HJ, Ali ZA, Kojima Y, Kundu RK, Sheikh AY, Agrawal R, et al. Apelin signaling antagonizes Ang II

effects in mouse models of atherosclerosis. J Clin Invest. 2008;118:3343-54.

72. Pchejetski D, Foussal C, Alfarano C, Lairez O, Calise D, Guilbeau-Frugier C, et al. Apelin prevents cardiac fibro- blast activation and collagen production through inhibition of sphingosine kinase 1. Eur Heart J.2012;33:2360-9.

73. Nagpal V, Rai R, Place AT, Murphy SB, Verma SK, Ghosh AK, et al. MiR-125b is critical for fibroblast-to- myofibroblast transition and cardiac fibrosis. Circulation. 2016;1333:291-301.

74. Ohukainen P, Syvaranta S, Napankangas J, Rajamaki K, Taskinen P, Peltonen T, et al. MicroRNA-125b and che- mokine CCL4 expression are associated with calcific aortic valve disease. Ann Med. 2015;47:423-9.

75. Yan W, Wu F, Morser J, Wu Q. Corin, a transmembrane cardiac serine protease, acts as a pro-atrial natriuretic peptideconverting enzyme. Proc Natl Acad Sci USA. 2000;97:8525-9.

76. Wu C, Wu F, Pan J, Morser J, Wu Q. Furin-mediated processing of Pro-C-type natriuretic peptide. J Biol Chem. 2003;278:2584752.

77. Peltonen TO, Taskinen P, Soini Y, Rysa J, Ronkainen J, Ohtonen P, et al. Distinct downregulation of C-type natriuretic peptide system in human aortic valve sten- osis. Circulation. 2007;116:1283-9.

78. Chusho H, Tamura N, Ogawa Y, Yasoda A, Suda M, Miyazawa T, et al. Dwarfism and early death in mice lacking C-type natriuretic peptide. Proc Natl Acad Sci USA. 2001;98:4016-21.

79. Komatsu Y, Chusho H, Tamura N, Yasoda A, Miyazawa T, Suda M, et al. Significance of C-type natri- uretic peptide (CNP) in endochondral ossification: ana- lysis of CNP knockout mice. J Bone Miner Metab. 2002;20:331-6.

80. Chen JJ, Zhang J, Cai Y, Zhou YB, Wen GB, Tang CS, et al. C-type natriuretic peptide inhibiting vascular cal-cification might involve decreasing bone morphogenic protein 2 and osteopontin levels. Mol Cell Biochem. 2014;392:65-76.

81. Kimura T, Nojiri T, Hino J, Hosoda H, Miura K, Shintani Y, et al. C-type natriuretic peptide ameliorates pulmonary fibrosis by acting on lung fibroblasts in mice. Respir Res. 2016;17:19

82. Qian JY, Haruno A, Asada Y, Nishida T, Saito Y, Matsuda T, et al. Local expression of C-type natriuretic peptide suppresses inflammation, eliminates shear stress-induced thrombosis, and prevents neointimalformation through enhanced nitric oxide production in rabbit injured carotid arteries. Circ Res. 2002;91:1063-9.

83. Yip CY, Blaser MC, Mirzaei Z, Zhong X, Simmons CA. Inhibition of pathological differentiation of valvular interstitial cells by Ctype natriuretic peptide. Arterioscler Thromb Vasc Biol. 2011;31:1881-9.

84. Moyes AJ, Khambata RS, Villar I, Bubb KJ, Baliga RS, Lumsden NG, et al. Endothelial C-type natriuretic pep- tide maintains vascular homeostasis. J Clin Invest. 2014;124:4039-51.

85. Krejci $\mathrm{P}$, Masri B, Fontaine V, Mekikian PB, Weis $M$, Prats $H$, et al. Interaction of fibroblast growth factor and C-natriuretic peptide signaling in regulation of chondrocyte proliferation and extracellular matrix homeostasis. J Cell Sci. 2005;118:5089100.

86. Satta J, Oiva J, Salo T, Eriksen H, Ohtonen P, Biancari F, et al. Evidence for an altered balance between matrix metalloproteinase-9 and its inhibitors in calcific aortic stenosis. Ann Thorac Surg. 2003;76:681-8.

87. Hubers SA, Brown NJ. Combined angiotensin receptor antagonism and neprilysin inhibition. Circulation. 2016;13311:111524.

88. McMurray JJ, Packer M, Desai AS, Gong J, Lefkowitz MP, Rizkala AR, et al. Angiotensin-neprilysin inhibition versus enalapril 
in heart failure. N Engl J Med. 2014;371:993-1004.

89. Steadman CD, Ray S, Ng LL, McCann GP. Natriuretic peptides in common valvular heart disease. J Am Coll Cardiol. 2010;55:2034-48.

90. Cimadevilla C, Cueff C, Hekimian G, Dehoux M, Lepage L, lung B, et al. Prognostic value of B-type natriuretic peptide in elderly patients with aortic valve stenosis: the COFRASA-GENERAC study. Heart. 2013;99:461-7.

91. Clavel MA, Malouf J, Michelena HI, Suri RM, Jaffe AS, Mahoney DW, et al. B-type natriuretic peptide clinical activation in aortic stenosis: impact on long-term sur-vival. J Am Coll Cardiol. 2014;63:2016-25.

92. Vahanian A, Alfieri O, Andreotti F Antunes MJ, et al. Joint task force on the management of valvular heart disease of the European Society of Cardiology (ESC), European Association for Cardio-Thoracic Surgery (EACTS). Guidelines on the management of valvular heart disease (version 2012). Eur Heart J.2012;3319:2451-96.

93. Peltonen T, Ohtonen P, Nâpankangas J, Ohukainen $P$,

Ruskoaho H, Taskinen P. Statin treatment and gene expression of anti-atherogenic factor C-type natriuretic peptide system in stenotic aortic valves. J Heart Valve Dis. 2011;205:545-51. 